\title{
Article \\ Exploiting Plant Functional Diversity in Durum Wheat-Lentil Relay Intercropping to Stabilize Crop Yields under Contrasting Climatic Conditions
}

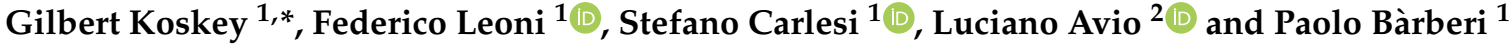 \\ 1 Group of Agroecology, Institute of Life Sciences, Scuola Superiore Sant'Anna, Piazza Martiri della Libertà, 33, \\ 56127 Pisa, Italy; federico.leoni@santannapisa.it (F.L.); stefano.carlesi@santannapisa.it (S.C.); \\ paolo.barberi@santannapisa.it (P.B.) \\ 2 Department of Agriculture, Food and Environment, University of Pisa, Via del Borghetto 80, 56124 Pisa, Italy; \\ luciano.avio@unipi.it \\ * Correspondence: gilbert.koskey@santannapisa.it
}

check for

updates

Citation: Koskey, G.; Leoni, F.;

Carlesi, S.; Avio, L.; Bàrberi, P.

Exploiting Plant Functional Diversity in Durum Wheat-Lentil Relay Intercropping to Stabilize Crop Yields under Contrasting Climatic

Conditions. Agronomy 2022, 12, 210.

https://doi.org/10.3390/

agronomy12010210

Academic Editor: Emily A.

Poppenborg Martin

Received: 17 December 2021

Accepted: 13 January 2022

Published: 16 January 2022

Publisher's Note: MDPI stays neutral with regard to jurisdictional claims in published maps and institutional affiliations.

Copyright: (C) 2022 by the authors. Licensee MDPI, Basel, Switzerland. This article is an open access article distributed under the terms and conditions of the Creative Commons Attribution (CC BY) license (https:// creativecommons.org/licenses/by/ $4.0 /$ )

\begin{abstract}
Relay intercropping is considered a valuable agroecological practice to increase and stabilize crop yields while ensuring the provision of several ecosystem services as well as sustainability and resilience to changing climatic conditions. However, farmers are still reluctant in the use of intercropping practices since there is a huge knowledge gap regarding the time of sowing, sowing ratio, crop stand density, and cultivar choice. In this study, we carried out a 3-year field experiment in Central Italy to assess the effect of relay intercropping on the agronomic performance and competitiveness of winter durum wheat (Triticum durum Desf. cv. Minosse) and spring lentil (Lens culinaris Medik. cv. Elsa) under a low-input management system, comparing different crop stand types (monocrop vs. intercrop) and target plant densities (350 plants $\mathrm{m}^{2}$-full dose vs. 116 plants $\mathrm{m}^{2}-1 / 3$ dose). The results revealed that intercropping increased grain yield compared to monocropping: significantly $(p<0.0001)$ against both monocrops in 2021 and non-significantly against durum wheat in 2019 and 2020. Yield advantage in both intercropping systems ranged between 164 and 648\%. Durum wheat competitiveness was stronger in 2019 and 2021, while lentil was the most competitive component in 2020. Intercropping favored P accumulation in durum wheat shoots. There was no difference in grain yield of both crops between the highly- and lowly-dense system in 2020 and 2021. Both intercropping strategies were as effective as mechanical hoeing in controlling weeds and proved beneficial in stabilizing lentil productivity. Further economic analysis capturing the additional costs incurred in intercropping and mechanical weeding would highlight the magnitude of profitability of these systems.
\end{abstract}

Keywords: agroecology; competition; resource use complementarity; facilitation; land equivalent ratio; sowing ratio; crop stand density

\section{Introduction}

Globally, there is a need to address the issue of meeting food security using the available natural resources amidst the shrinking of total arable land, and rising human population and food demand [1,2]. This is becoming more challenging considering the need to reduce greenhouse gas emissions, maintain ecosystem sustainability, and reduce the environmental impacts associated with agricultural intensification and climate change [3,4]. Relay intercropping is an agroecological practice that allows the cultivation of two or more crops that complementarily exploit resources within time and space while limiting the use of external inputs $[5,6]$. It is considered a valuable tool for the agroecological transition of current cropping systems and aims to optimize crop yields while ensuring ecosystem sustainability, resilience, profitability, and yield stability amidst the changing climatic conditions [2,7], particularly in low-input and organic farming systems [8]. 
Under low-input systems, durum wheat (Triticum durum Desf.) productivity and yield quality significantly vary because of the interaction between erratic rainfall and limited use of external inputs. The yield variations are further exacerbated by the effects of the changing Mediterranean climatic conditions [9]. This variability questions the economic viability and sustainability of durum wheat monocropping under low input systems, unlike in the conventional systems. Diversifying cropping systems, through targeted functional traits of intercrops, and enhancing the delivery of agroecosystem services, through the inclusion of legumes such as lentils (Lens culinaris Medik.), can minimize the limiting interaction effects associated with monocropping. Moreover, there is a growing consumption demand in Europe for lentil yet its production in the region remains low [10].

The different phenologies and morphologies of durum wheat-lentil intercrops offer room to maximize aboveground interspecific interactions in the utilization of light and space at canopy level [11] to control weeds [12], and to enhance the below-ground interactions in terms of nutrient acquisition, niche differentiation, and complementary utilization of bio-resources [13,14]. Moreover, co-cultivation of cereal with legumes increases the root exudation of allelopathic and nodulation promoting compounds increasing nitrogen fixation ability and competitiveness against weeds [15]. Therefore, increasing plant species diversity with complementary functional traits through relay intercropping present an interesting opportunity to develop positive interactions that enhance ecosystem service provisioning within space and time.

Previous studies on legume-durum wheat mixtures have reported increased overall grain yield and quality, aboveground biomass, gross margin, and land equivalent ratio (LER) of the durum wheat-faba bean [16], durum wheat-winter pea [17], and durum wheat-chickpea [18] intercrops compared to the sole crops. In addition, cereal-legume intercropping has been shown to improve profitability [10], increase the cereal's $\mathrm{N}$ and P uptake [19] and grain protein concentration [20], provide physical support to vining legumes hence reducing lodging [21], enhance mechanical harvesting efficiency and seed quality [21,22], improve soil $\mathrm{N}$ and soil health [23], and reduce global use of synthetic fertilizers and greenhouse gas emissions [4]. Most of these studies have focused on the intercrop productivity without considering the effect of reducing the plant density of the dominant crop or altering the sowing time of the companion crop. The information is further limited in the context of relay intercropping durum wheat and lentil managed under a low-input system under Mediterranean field conditions and in the context of changing climatic conditions.

An intercropping study by Latati et al. [18] showed intense competition between chickpea and durum wheat sown at 100\%:67\% ratio, respectively, while Loïc et al. [10] reported a unidirectional competition by spring wheat on lentil sown at $17 \%: 100 \%$ density ratio, respectively. These contrasting findings reinforce the need for studies that identify compatible cultivars and optimize intercrop geometry in terms of row spacing, sowing proportions, and plant density within an intercropping system that minimize interspecific competition and aggressivity [12] and create a microenvironment at the root and canopy level that soothes the plants from moisture, wind, and heat-related stresses [2]. This is expected to reduce the risk of total yield losses amidst the changing climatic conditions and improve yield stability, unlike monocropping.

Contemporary wheat-lentil intercropping has been explored by different authors such as Loïc et al. [10], Wang et al. [21] and Akter et al. [24]; however, contemporary intercropping may not be suitable in certain geo-climatic areas due to temperature sensitivity and biological cycle of the two crops. The Mediterranean climate allows the sowing of winter durum wheat in October-December [25], followed by relay intercropping of lentil in February-March of each season. The two crops reach maturity nearly at the same time (early summer), thus allowing combined mechanical harvesting and separation. Thus, relay intercropping presents a viable solution to exploit the ecological advantage of intercropping in certain geo-climatic areas. To the best of our knowledge, this experiment represents the first three-year open field study in durum wheat-lentil relay intercropping. 
In this work, we carried out a 3-year field experiment to assess the effect of crop functional diversity in relay intercropping of durum wheat and lentil under a low-input farming system, comparing different crop stand types (monocrop vs. intercrop) and target plant densities (high-100\% vs. low-33\% durum wheat density with $100 \%$ constant lentil density) on the crop agronomic performance and competitiveness. We tested the following four hypotheses: (i) relay intercropping will enhance the overall crop productivity, more so, in the less dense intercropping system; (ii) reducing wheat density to $33 \%$ in intercropping will lower wheat competition on lentil production compared to the highlydense durum wheat intercrops, while maintaining the expected intercropping ecosystem services; (iii) incorporation of lentil into the already grown durum wheat will enhance $P$ uptake in durum wheat; and (iv) incorporation of durum wheat in the intercropping will provide a supportive microenvironment that enhances lentil competitive ability against weeds, hence maximizing its productivity.

\section{Materials and Methods}

\subsection{Experimental Site, Soil, and Climate}

The field experiments were carried out at the Interdepartmental Centre for AgriEnvironmental Research Enrico Avanzi (CiRAA) of the University of Pisa $\left(43^{\circ} 40^{\prime} 48.0^{\prime \prime} \mathrm{N}\right.$, $10^{\circ} 20^{\prime} 45.5^{\prime \prime} \mathrm{E}$ ). The trials were replicated across three consecutive growing seasons (2019, 2020 , and 2021) in three separate but adjacent fields, which were managed to simulate a rainfed, low input system with no use of chemical fertilizers, herbicides, or pesticides. Seedbed preparation involved a moldboard ploughing to $25 \mathrm{~cm}$ depth followed by a shallow $(10 \mathrm{~cm}$ depth) disc harrowing. Soils are classified as Typic Xerofluvent by USDA [26] and as Fluvisol by FAO [27], with alkaline sandy loam texture (51\% sand, $40 \%$ silt, and $9 \%$ clay), $\mathrm{pH}\left(1: 1 \mathrm{H}_{2} \mathrm{O}\right)$ of $8.33,1.23 \mathrm{~g} \mathrm{~kg}^{-1}$ total $\mathrm{N}$ (Kjeldahl method, [28]), 1.18\% organic carbon (Walkley-Black method, [29]), and $16.04 \mathrm{mg} \mathrm{kg}^{-1}$ available $\mathrm{P}_{2} \mathrm{O}_{5}$ (Olsen method, [30]). The total mean monthly rainfall during the first three months (November to January) critical for durum wheat planting, germination, and shooting was $221 \mathrm{~mm}, 471 \mathrm{~mm}$, and $554 \mathrm{~mm}$ in year one, two and three, respectively (Figure 1). The 25-year mean total rainfall of the experimental site within the same period is $327 \mathrm{~mm}$.

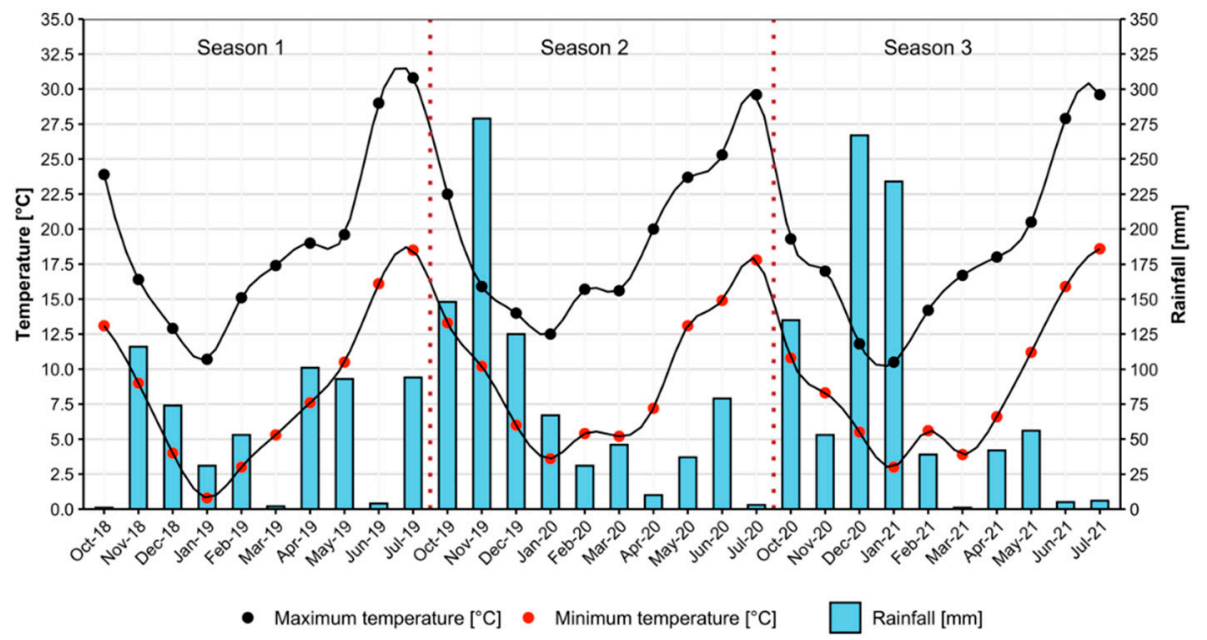

Figure 1. Average monthly rainfall and temperature (maximum and minimum) at San Piero a Grado (Pisa, Central Italy) from October 2018 to July 2021.

\subsection{Cropping and Field Design}

The trial involved relay intercropping of winter durum wheat (Triticum durum Desf. cv. Minosse) with lentil (Lens culinaris Medik. cv. Elsa). The cultivars were chosen because of their growth and phenological complementarity. Lentil Medik. cv. Elsa produces large, marbled green to yellow seeds and has a medium-late growth cycle that synchronizes well if relay intercropped in early spring with autumn-sown durum wheat. In addition, 
it grows up to $45-48 \mathrm{~cm}$ in height and, therefore, could benefit from wheat support. Its high protein content (24-26\%) and ability to tolerate cold and water stress makes it ideal for Mediterranean conditions [31]. Durum wheat cv. Minosse has a high protein content, and excellent environmental adaptability, an important factor for the crop to withstand the changes brought about by the modified intercropping microenvironment. It grows to a height of $80-85 \mathrm{~cm}$ [32]. Both crop cultivars were procured from the Agroservice S.P.A. seed producers (Marche, Italy).

We used a randomized complete block design (RCBD) with four replications in the first year and five replicates in the second and third year. The crop-stand type treatments included: (i) sole cropping of (a) 100\% durum wheat and (b) 100\% lentil; (ii) relay intercrops of (a) 100\% lentil $+33 \%$ wheat density (low dose) and (b) $100 \%$ lentil $+100 \%$ wheat density (high dose). In the second and third year, an additional lentil monoculture plot that involved mechanical weeding was introduced. The target crop densities for the sole crops were $100 \%$, i.e., 350 plants $\mathrm{m}^{-2}$ for durum wheat and 180 plants $\mathrm{m}^{-2}$ for lentil, and 116 plants $\mathrm{m}^{-2}$ for the low $(33 \%)$ wheat density in the intercropping system.

In winter (18-11-2018 for year 1, 08-01-2020 for year 2 (heavy rains delayed sowing), and 20-11-2020 for year 3), durum wheat was sown in medium-spaced rows $18 \mathrm{~cm}$ apart using a mechanical plot seeder. Each plot $(3 \mathrm{~m}$ width $\times 8 \mathrm{~m}$ long) consisted of 16 rows of durum wheat and/or 16 inter-rows of lentil depending on the treatment. Lentil, as monocrop and relay intercrop of the already established durum wheat, was sown at the end of February of each season. The plant density and plot size of the weeded lentil sole crop remained the same, but the number of rows was adjusted to eight due to wider spacing (36 cm apart), which was adopted to allow the use of inter-row hoeing. Lentil plots requiring weeding were mechanically hoed once at $5 \mathrm{~cm}$ depth at the end of April of each year.

Lentil seedling emergence was, on average, consistently congruent with the targeted density $(108 \%, 2019 ; 113 \%, 2020$ and 110\%, 2021) in all the treatments (Table S1), while that of durum wheat was significantly reduced only in the third year $(91 \%, 2019 ; 97 \%, 2020$ and $47 \%, 2021)$. Despite the wheat emergence reduction in the third year, the actual difference between the $100 \%$ and $33 \%$ density ratio was maintained (Table S1).

The growth cycle of the durum wheat and lentil was monitored, and the BBCH growth scale (GS), described by Meier et al. [33], was used to identify the crop phenological stage. Due to the synchronized growth habit of durum wheat and lentil, sampling of both crops was performed simultaneously, and only inner rows were considered in all the assessments to avoid border effects. Weeds growing within the plant rows and fitting in the sampling quadrat were assessed for dry biomass density.

\subsection{Plant Measurements, Processing, and Calculations}

Crop establishment was assessed 30 days after sowing (DAS) using $25 \times 36 \mathrm{~cm}$ threereplicate quadrats per plot. The number of wheat tillers $\mathrm{m}^{-2}$ was assessed at the end of tillering (BBCH GS 29) in three replicate quadrats of $25 \times 36 \mathrm{~cm}$ per plot. Tillering index (TI) ratio was calculated by dividing the number of durum wheat tillers by the number of emerged plants [34]. At the harvesting stage (BBCH GS 92), both crop and weed aboveground biomasses were cut at the base in three $54 \times 50 \mathrm{~cm}$ quadrats per plot. In mechanically weeded lentil plots, three quadrats of $72 \times 50 \mathrm{~cm}$ were used instead. Biomass samples from the intercrops were separated into weeds, durum wheat, and lentil before processing. Biomass dry weight $\left(\mathrm{g} \mathrm{m}^{-2}\right)$ of the samples was obtained by oven-drying at $60{ }^{\circ} \mathrm{C}$ until a constant weight. The durum wheat samples were further assessed for the number of spikes $\mathrm{m}^{-2}$, spike biomass, and straw biomass. Threshing of wheat and lentil was carried out mechanically and separately to obtain clean grains, which were weighed to obtain grain yield $\left(\mathrm{t} \mathrm{ha}^{-1}\right)$. Plot-based harvesting index (HI), LER, and shoot biomass nutrition quality (P-Olsen method, [30]) were determined. LER and competition indices were used to determine the yield advantages of intercropping over sole cropping and assess the competition between durum wheat and lentil intercrops. 
LER calculations were performed according to Willey and Rao [35] as follows:

$$
\mathrm{LER}=\mathrm{LER}_{\text {wheat }}+\mathrm{LER}_{\text {lentil }}=\left(\mathrm{Y}_{\mathrm{WI}} / \mathrm{Y}_{\mathrm{WS}}\right)+\left(\mathrm{Y}_{\mathrm{LI}} / \mathrm{Y}_{\mathrm{LS}}\right)
$$

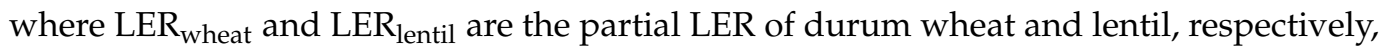
and $Y_{\mathrm{WI}} / \mathrm{Y}_{\mathrm{LI}}$ and $\mathrm{Y}_{\mathrm{WS}} / \mathrm{Y}_{\mathrm{LS}}$ are the grain yields of durum wheat/lentil in the intercrop mixture and sole crop, respectively. An LER value $>1$ indicates the intercropping advantage, while LER $<1$ indicates that intercropping negatively affects the growth and yield of the components [36].

Aggressivity (A): Indicates how much the relative yield increase of the main crop (in our case durum wheat) is greater than that of the intercrop (lentil) in the relay intercropping system [37].

$$
\mathrm{A}_{\text {wheat }}=\left\{\mathrm{Y}_{\mathrm{WI}} /\left(\mathrm{Y}_{\mathrm{WS}} \times \mathrm{Z}_{\mathrm{WI}}\right)\right\}-\left\{\mathrm{Y}_{\mathrm{LI}} /\left(\mathrm{Y}_{\mathrm{LS}} \times \mathrm{Z}_{\mathrm{LI}}\right)\right\}
$$

where $Z_{\mathrm{LI}}$ and $\mathrm{Z}_{\mathrm{WI}}$ are the sown proportions of lentil and wheat in the intercrop mixture, respectively. $A_{\text {wheat }}=0$ indicates that both intercrops are equally competitive; $A_{\text {wheat }}>0$ suggests that wheat is more dominant while $A_{\text {wheat }}<0$ indicates that wheat species is dominated by lentil [38].

Competitive ratio (CR): Refers to the ratio of the partial LERs of the two intercrops taking into account their sowing proportions [35].

$$
\begin{aligned}
& \mathrm{CR}_{\text {wheat }}=\left(\mathrm{LER}_{\text {wheat }} / \mathrm{LER}_{\text {lentil }}\right) \times\left(\mathrm{Z}_{\mathrm{LI}} / \mathrm{Z}_{\mathrm{WI}}\right) \\
& \mathrm{CR}_{\text {lentil }}=\left(\mathrm{LER}_{\text {lentil }} / \mathrm{LER}_{\text {wheat }}\right) \times\left(\mathrm{Z}_{\mathrm{WI}} / \mathrm{Z}_{\mathrm{LI}}\right)
\end{aligned}
$$

\subsection{Statistical Analyses}

The data were analyzed in $\mathrm{R}$ software (version 4.1.0) [39] to determine the effect of varying durum wheat density and intercropping system on various plant agronomic parameters. Whenever present, blocks and within-plot pseudo-replicates were used as random factors while crop stand type and year were used as fixed factors. Year was treated as a fixed factor only if there was a significant year $x$ treatment interaction. Spike number and biomass, HI, LER, A, CR, grain yield, and P content were analyzed using a generalized linear mixed model (GLMM) in 'Lme4' R package with a Gaussian or log link distribution function [40]. Whenever applicable, the data presented were back transformed to an ordinal scale. Tukey's post hoc test using R/emmeans [41] was run in each model to check for significant differences at $p<0.05$.

The significance of explanatory variables was tested by using a maximum likelihood (ML) ratio test while the Akaike Information Criteria [42] was used for refining model comparison. In order to test the model assumptions (normality, homogeneity of variances, violation of independence), the Shapiro-Wilk tests were performed, complemented by graphical assessments of the model residuals. Kolmogorov-Smirnov test of normality in the 'DHARMa' R package [43] was also used to assess the goodness of fit on the scaled residuals of the chosen models. Pearson correlations were performed to test for any relevant associations among the agronomical parameters. Principal component analysis (PCA), based on a standardized correlation matrix, was used to examine the variation of production-related variables (grain yield, HI, wheat spike components, aboveground biomass, and weed biomass) in sole cropped and intercropped systems. PCA was performed separately for each crop. Kaiser criterion [44] was used to determine the principal components (PCs) that account for the highest variation, supported by scree plot representation.

\section{Results}

\subsection{Effect of Crop Stand Density Type on Durum Wheat Tillering Index (TI)}

Wheat sowing density $(p<0.0001)$ and year $(p<0.0001)$ significantly influenced durum wheat TI (Table 1). Compared to the highly dense wheat intercrop, TI was on average $45 \%$, $66 \%$, and $100 \%$ higher under low wheat density in 2019, 2020, and 2021, respectively. In 
contrast, no TI difference was observed between the highly dense wheat intercrop and wheat monocrop. Averaged across all the treatments, durum wheat had the highest (2.06) TI in 2019 and the lowest (0.97) in 2020 (Table 1).

Table 1. Durum wheat tillering index (TI) and aboveground crop biomass of intercrops.

\begin{tabular}{|c|c|c|c|c|c|}
\hline \multirow{2}{*}{ Year } & \multirow{2}{*}{$\begin{array}{l}\text { Intercropping } \\
\text { System }\end{array}$} & \multirow{2}{*}{$\begin{array}{l}\text { Tillering Index } \\
\text { (TI) }\end{array}$} & \multicolumn{3}{|c|}{ Aboveground Crop Biomass ( $\left(\mathrm{ha}^{-1}\right.$ ) at Harvest } \\
\hline & & & Lentil & Wheat & Total Intercrop \\
\hline \multirow{4}{*}{2019} & Weeded sole crop & - & - & - & - \\
\hline & Sole crop & $1.64(0.11) \mathrm{bA}$ & $4.26(0.53) \mathrm{aA}$ & $12.87(0.67) \mathrm{aA}$ & - \\
\hline & 100\% Mix & $1.86(0.22) \mathrm{bA}$ & $1.93(0.24) b B$ & $11.62(0.38)$ abA & $13.55(0.47) \mathrm{aA}$ \\
\hline & $33 \%$ Mix & $2.69(0.40) \mathrm{aA}$ & $2.97(0.28) \mathrm{abA}$ & $11.06(0.45) \mathrm{bA}$ & $14.03(0.23) \mathrm{aA}$ \\
\hline \multirow{4}{*}{2020} & Weeded sole crop & - & $3.59(0.25) \mathrm{aA}$ & - & - \\
\hline & Sole crop & $0.89(0.06) \mathrm{bB}$ & $2.27(0.31) \mathrm{bB}$ & $7.30(0.33) \mathrm{aB}$ & - \\
\hline & 100\% Mix & $0.76(0.03) b B$ & $3.04(0.33) \mathrm{abA}$ & $5.07(0.44) \mathrm{bB}$ & $8.12(0.19) \mathrm{aB}$ \\
\hline & $33 \%$ Mix & $1.26(0.09) \mathrm{aB}$ & $3.03(0.25) \mathrm{abA}$ & $4.56(0.29) \mathrm{bB}$ & $7.59(0.73) \mathrm{aB}$ \\
\hline \multirow{4}{*}{2021} & Weeded sole crop & - & $2.85(0.17) \mathrm{bA}$ & - & - \\
\hline & Sole crop & $1.61(0.23) \mathrm{bA}$ & $4.25(0.34) \mathrm{aA}$ & $5.30(0.32) \mathrm{aC}$ & - \\
\hline & 100\% Mix & $1.16(0.09) \mathrm{bA}$ & $3.37(0.25)$ abA & $5.14(0.38) \mathrm{aB}$ & $8.50(0.39) \mathrm{aB}$ \\
\hline & $33 \%$ Mix & $2.32(0.29) \mathrm{aA}$ & 3.49 (0.18) abA & $5.03(0.32) \mathrm{aB}$ & $8.52(0.37) \mathrm{aB}$ \\
\hline \multirow{3}{*}{$p$-values } & Intercropping & $<0.0001$ & 0.047 & $<0.0001$ & 0.718 \\
\hline & Year & $<0.0001$ & 0.004 & $<0.0001$ & $<0.0001$ \\
\hline & Int. $\times$ Year & 0.45 & $<0.0001$ & 0.016 & 0.345 \\
\hline
\end{tabular}

\subsection{Effect of Relay Intercropping on Aboveground Crop Biomass at Harvest}

The interaction between intercropping density and year significantly $(p<0.05)$ influenced the individual crop species biomass (Table 1). Considering all the un-weeded treatments together, the mean aboveground biomass at harvesting was significantly higher in intercrops (durum wheat + lentil) compared to that of lentil sole crop across the three seasons (13.8 $\mathrm{tha}^{-1}, 7.8 \mathrm{tha}^{-1}$, and $8.5 \mathrm{t} \mathrm{ha}^{-1}$ vs. $4.3 \mathrm{t} \mathrm{ha}^{-1}, 2.3 \mathrm{t} \mathrm{ha}^{-1}$, and $4.2 \mathrm{t} \mathrm{ha}^{-1}$, in $2019,2020$, and 2021, respectively; $p<0.0001)$, and wheat sole crop only in $2021\left(8.5 \mathrm{tha}^{-1}\right.$ vs. $5.3 \mathrm{tha}^{-1}$, respectively; $\left.p<0.0001\right)$. A significant $(p<0.0001)$ year difference was also detected, whereby, on average, the total intercrop biomass in $2019\left(11.18 \pm 0.48 \mathrm{t} \mathrm{ha}^{-1}\right)$ was significantly higher than $2020\left(6.32 \pm 0.38 \mathrm{t} \mathrm{ha}^{-1}\right)$ and $2021\left(6.64 \pm 0.43 \mathrm{t} \mathrm{ha}^{-1}\right)$. At the crop species level, relay intercropping significantly $(p<0.001)$ reduced the biomass of lentil in 2019 (2.45 $\mathrm{t} \mathrm{ha}^{-1}$ vs. $4.26 \mathrm{t} \mathrm{ha}^{-1}$, respectively) and 2021 (3.43 $\mathrm{t} \mathrm{ha}^{-1}$ vs. $4.25 \mathrm{t} \mathrm{ha}^{-1}$, respectively), and that of durum wheat $(p<0.001)$ in $2019\left(11.3 \mathrm{t} \mathrm{ha}^{-1} \mathrm{vs.} 12.9 \mathrm{t} \mathrm{ha}^{-1}\right.$, respectively) and 2020 ( $4.8 \mathrm{tha}^{-1}$ vs. $7.3 \mathrm{t} \mathrm{ha}^{-1}$, respectively), compared to their respective sole crop (Table 1). Interestingly, within the intercropping system, reducing wheat sowing density in 2019 marginally (5\%) reduced durum wheat biomass but enhanced the lentil biomass by $53 \%$ unlike in 2020 and 2021 where no differences were detected. Mechanical weeding increased lentil biomass by $58 \%$ in 2020 but reduced it by $33 \%$ in 2021 compared to the un-weeded lentil (Table 1).

\subsection{Effect of Relay Intercropping on the Total Grain Yield}

The total intercrop (durum wheat + lentil) grain yield was significantly $(p<0.0001)$ affected by the interaction between intercrop density and year (Table 2). Although there was a yield variation $(p<0.0001)$ across the years, the grain yield of the mixture (durum 
wheat + lentil) was higher than that of wheat monoculture, significantly in $2021\left(3.42 \mathrm{tha}^{-1}\right.$ vs. $2.32 \mathrm{tha}^{-1}$, respectively) but non-significantly in $2019\left(5.41 \mathrm{tha}^{-1}\right.$ vs. $5.20 \mathrm{t} \mathrm{ha}^{-1}$, respectively) and 2020 (2.94 tha ${ }^{-1}$ vs. $2.82 \mathrm{t} \mathrm{ha}^{-1}$, respectively). Overall, the 2019 total crop harvest was the highest $\left(4.27 \pm 0.17 \mathrm{t} \mathrm{ha}^{-1}\right)$, while the least $\left(2.24 \pm 0.14 \mathrm{tha}^{-1}\right)$ production was recorded in 2020, which did not differ from that of $2021\left(2.62 \pm 0.18 \mathrm{tha}^{-1}\right)$ (Table 2). At the species level, lentil performed better in 2021, recording $21 \%$ and $46 \%$ higher grain yield than 2019 and 2020, respectively, while a two-fold increase in durum wheat production was recorded in 2019 compared to 2020 and 2021 seasons. On average, a reduction effect of relay intercropping on grain yield was detected only in the intercropped durum wheat $(-15 \%$, $2019 ;-35 \%, 2020)$ and not in lentil, in comparison to their sole crops. Interestingly, reducing wheat density in the intercropping did not greatly lower $(-3 \%, 2019 ;-13 \%, 2020$; and $-1 \%$, 2021) durum wheat grain production compared to the highly dense intercropping system. Instead, in 2020, there was a four-fold grain yield increase in lentil produced through the intercropping system vis-à-vis the lentil sole crop. Mechanical weeding of lentil sole crop enhanced $(p<0.001)$ grain production by $183 \%$ in 2020 but had no significant effect $(-25 \%$, $p=0.304$ ) in 2021 compared to the un-weeded lentil sole crop (Table 2).

Table 2. Total intercrop and specific grain yield and harvest index (HI) of durum wheat and lentil at harvest.

\begin{tabular}{|c|c|c|c|c|c|c|}
\hline \multirow{2}{*}{ Year } & \multirow{2}{*}{$\begin{array}{l}\text { Intercropping } \\
\text { System }\end{array}$} & \multicolumn{3}{|c|}{ Crop Grain Yield (t ha ${ }^{-1}$ ) } & \multicolumn{2}{|c|}{ Harvest Index (HI) } \\
\hline & & Lentil & Wheat & Total Intercrop & Lentil HI & Wheat HI \\
\hline \multirow{4}{*}{2019} & Weeded sole crop & - & - & - & - & - \\
\hline & Sole crop & $1.04(0.12) \mathrm{aA}$ & $5.20(0.26) \mathrm{aA}$ & - & $0.253(0.031) \mathrm{bA}$ & $0.404(0.005) \mathrm{aB}$ \\
\hline & 100\% Mix & $0.77(0.11) \mathrm{aA}$ & $4.49(0.15) \mathrm{abA}$ & $5.26(0.24) \mathrm{aA}$ & $0.396(0.018) \mathrm{aA}$ & $0.386(0.003) \mathrm{aB}$ \\
\hline & $33 \%$ Mix & $1.24(0.14) \mathrm{aA}$ & $4.33(0.15) \mathrm{bA}$ & $5.57(0.11) \mathrm{aA}$ & $0.414(0.015) \mathrm{aA}$ & $0.392(0.007) \mathrm{aB}$ \\
\hline \multirow{4}{*}{2020} & Weeded sole crop & $0.79(0.07) \mathrm{aA}$ & - & - & $0.220(0.010) \mathrm{bB}$ & - \\
\hline & Sole crop & $0.28(0.08) \mathrm{bB}$ & $2.82(0.13) \mathrm{aB}$ & - & $0.115(0.018) \mathrm{cB}$ & $0.386(0.002) \mathrm{aB}$ \\
\hline & 100\% Mix & $1.20(0.14) \mathrm{aA}$ & $1.95(0.17) \mathrm{bB}$ & $3.15(0.10) \mathrm{aB}$ & $0.391(0.013) \mathrm{aA}$ & $0.383(0.001) \mathrm{aB}$ \\
\hline & $33 \%$ Mix & $1.05(0.10) \mathrm{aA}$ & $1.68(0.11) b B$ & $2.73(0.28) \mathrm{aC}$ & $0.342(0.011) \mathrm{aB}$ & $0.368(0.003) \mathrm{aB}$ \\
\hline \multirow{4}{*}{2021} & Weeded sole crop & $0.96(0.08) \mathrm{aA}$ & - & - & $0.331(0.014) \mathrm{aA}$ & - \\
\hline & Sole crop & $1.29(0.10) \mathrm{aA}$ & $2.32(0.15) \mathrm{bB}$ & - & $0.308(0.016) \mathrm{aA}$ & $0.438(0.011) \mathrm{aA}$ \\
\hline & $100 \%$ Mix & $1.17(0.11) \mathrm{aA}$ & $2.23(0.18) \mathrm{aB}$ & $3.40(0.24) \mathrm{aB}$ & $0.338(0.012) \mathrm{aB}$ & $0.433(0.011) \mathrm{aA}$ \\
\hline & $33 \%$ Mix & $1.24(0.07) \mathrm{aA}$ & $2.21(0.15) \mathrm{aB}$ & $3.45(0.18) \mathrm{aB}$ & $\begin{array}{c}0.357(0.010) \\
\mathrm{aAB}\end{array}$ & $0.438(0.011) \mathrm{aA}$ \\
\hline \multirow{3}{*}{$p$-values } & Intercropping & 0.01 & $<0.0001$ & 0.579 & $<0.0001$ & 0.351 \\
\hline & Year & 0.0002 & 0.001 & $<0.0001$ & $<0.0001$ & $<0.0001$ \\
\hline & Int. $\times$ Year & $<0.0001$ & 0.708 & $<0.0001$ & $<0.0001$ & 0.604 \\
\hline
\end{tabular}

Values are treatment means (S.E); different lowercase letters within columns in each year indicate statistical significance at $p \leq 0.05$ level (Tukey's post hoc test) among treatments. Different uppercase letters within columns indicate statistically significant differences between years.

\subsection{Effect of Relay Intercropping on Crop Harvest Index (HI) and Durum Wheat Spike Productivity}

The HI of intercropped and sole cropped durum wheat did not significantly $(p=0.351)$ differ, but a mean year difference $(\mathrm{HI}=0.394,2019 ; 0.379,2020$ and $0.436,2021 ; p<0.0001)$ was observed (Table 2). On the contrary, relay intercropping significantly $(p<0.0001)$ enhanced lentil $\mathrm{HI}$ in 2019 (cumulative mean $\mathrm{HI}=0.405$ vs. 0.253) and 2020 (mean $\mathrm{HI}=0.367$ vs. 0.115 ) compared to the lentil sole crop (Table 2).

The interaction between intercropping density and year significantly influenced durum wheat spike number $(p=0.002)$ and spike biomass $(p=0.023)$ per unit area (Table S1). 
Across the three years, durum wheat intercropped at low density consistently had the lowest number of spikes $\mathrm{m}^{-2}$; nevertheless, the spike biomass did not significantly differ between the low and high wheat densities (Table S1).

\subsection{Effect of Relay Intercropping on Shoot P Concentration at Flowering}

At wheat flowering stage, the intercropping system had a significant but diametrically opposite effect on P concentration of durum wheat $(p=0.002)$ and lentil $(p<0.0001)$ shoots (Table 3). Shoot $P$ concentration in the intercrops was significantly, on average, lower $(-11 \%$ in $2019,-21 \%$ in 2020) than that of the un-weeded lentil sole crop, while for the durum wheat, shoot P concentration was significantly higher $(+10 \%$ in $2019,+12 \%$ in 2020$)$ in the intercrops than sole crops in both years (Table 3).

Table 3. Phosphorus (P) concentration of durum wheat and lentil shoots at flowering stage.

\begin{tabular}{cccc}
\hline \multirow{2}{*}{ Year } & $\begin{array}{c}\text { Intercropping } \\
\text { System }\end{array}$ & \multicolumn{2}{c}{ Phosphorus (P) Concentration (\%) } \\
\cline { 2 - 4 } & Weeded sole crop & Lentil & Durum Wheat \\
\hline \multirow{2}{*}{2019} & Sole control & $0.349(0.029) \mathrm{aA}$ & $0.199(0.012) \mathrm{bA}$ \\
\cline { 2 - 4 } & $100 \%$ Mix & $0.294(0.005) \mathrm{bA}$ & $0.216(0.012) \mathrm{abA}$ \\
\cline { 2 - 4 } & $33 \%$ Mix & $0.333(0.005) \mathrm{bA}$ & $0.229(0.003) \mathrm{aA}$ \\
\hline \multirow{2}{*}{2020} & Weeded sole crop & $0.266(0.010) \mathrm{bA}$ & - \\
\cline { 2 - 4 } & Sole control & $0.344(0.007) \mathrm{aA}$ & $0.136(0.007) \mathrm{bB}$ \\
\cline { 2 - 4 } & $100 \%$ Mix & $0.284(0.012) \mathrm{bA}$ & $0.146(0.013) \mathrm{abB}$ \\
\hline & $33 \%$ Mix & $0.284(0.014) \mathrm{bA}$ & $0.164(0.004) \mathrm{aB}$ \\
\hline$p$-values & Intercropping & $<0.0001$ & 0.002 \\
\cline { 2 - 4 } & Year & 0.06 & $<0.0001$ \\
\cline { 2 - 4 } & Int. $\times$ Year & 0.143 & 0.906 \\
\hline
\end{tabular}

Values are treatment means (S.E); different lowercase letters within columns in each year indicate statistical significance at $p \leq 0.05$ level (Tukey's post hoc test) among treatments. Different uppercase letters within columns indicate statistically significant differences between years.

3.6. Effect of Crop Density Variation in Intercropping on Land Equivalent Ratio, Aggressivity (A), and Competition Ratio (CR)

Based on wheat-lentil grain yield, the total LER in both intercropping systems was always $>1$ and differed across the three years, ranging from 1.64 to 6.48 (Table 4). Although the yield intercrop advantage was much more evident in 2020 (6.26 \pm 0.21$)$, the partial LER of durum wheat was the lowest $(0.66 \pm 0.05)$. In both intercropping systems, durum wheat dominance over lentil was not strongly $\left(\mathrm{A}_{\text {wheat }} \leq 0, p=0.067\right)$ detected across the three years (Table 4). However, in 2020 durum wheat was dominated by lentil as indicated by the strong negative aggressivity index $\left(\mathrm{A}_{\text {wheat }}=-3.29 \pm 1.11\right)$. The competitive ability of durum wheat over the intercropped lentil was evident in 2019 and 2021, while in 2020, lentil was more competitive than the intercropped durum wheat. Across the three years, durum wheat intercropped at low density had significantly $(p=0.002)$ higher CR values than the wheat intercropped at high density (Table 4). 
Table 4. Land equivalent ratio (LER), aggressivity (A) and competition ratio (CR).

\begin{tabular}{|c|c|c|c|c|c|c|c|}
\hline \multirow{2}{*}{ Year } & \multirow{2}{*}{$\begin{array}{l}\text { Intercropping } \\
\text { System }\end{array}$} & \multicolumn{3}{|c|}{ Land Equivalent Ratio (LER) } & \multirow{2}{*}{$\begin{array}{c}\begin{array}{c}\text { Aggressivity } \\
\text { (A) }\end{array} \\
A_{\text {wheat }}\end{array}$} & \multicolumn{2}{|c|}{ Competition Ratio (CR) } \\
\hline & & LER $_{\text {wheat }}$ & LER $_{\text {lentil }}$ & Total LER & & $\mathrm{CR}_{\text {wheat }}$ & $\mathrm{CR}_{\text {lentil }}$ \\
\hline \multirow{2}{*}{2019} & 100\% Mix & $0.86(0.01) \mathrm{aAB}$ & $0.78(0.18) \mathrm{aB}$ & $1.64(0.18) \mathrm{aB}$ & $0.04(0.09) \mathrm{aA}$ & $1.29(0.27) \mathrm{bA}$ & $0.91(0.21) \mathrm{aA}$ \\
\hline & $33 \%$ Mix & $0.83(0.03) \mathrm{aAB}$ & $1.19(0.09) \mathrm{aB}$ & $2.02(0.09) \mathrm{aB}$ & $-0.69(0.06) \mathrm{aA}$ & $2.15(0.17) \mathrm{aA}$ & $0.47(0.04) \mathrm{bA}$ \\
\hline \multirow{2}{*}{2020} & 100\% Mix & $0.70(0.06) \mathrm{aB}$ & $5.35(1.58) \mathrm{aA}$ & $6.05(1.61) \mathrm{aA}$ & $-2.32(0.78) \mathrm{aB}$ & $0.16(0.03) \mathrm{bB}$ & $7.51(1.90) \mathrm{aB}$ \\
\hline & $33 \%$ Mix & $0.61(0.07) \mathrm{aB}$ & $5.87(2.20) \mathrm{aA}$ & $6.48(2.25) \mathrm{aA}$ & $-4.26(1.64) \mathrm{aB}$ & $0.53(0.16) \mathrm{aB}$ & $2.98(0.94) b B$ \\
\hline \multirow{2}{*}{2021} & $100 \%$ Mix & $0.97(0.09) \mathrm{aA}$ & $0.91(0.14) \mathrm{aB}$ & $1.88(0.14) \mathrm{aB}$ & $0.03(0.09) \mathrm{aA}$ & $1.21(0.26) \mathrm{bA}$ & $0.99(0.19) \mathrm{aA}$ \\
\hline & $33 \%$ Mix & $0.99(0.13) \mathrm{aA}$ & $0.99(0.11) \mathrm{aB}$ & $1.98(0.08) \mathrm{aB}$ & $-0.50(0.11) \mathrm{aA}$ & $3.41(0.89) \mathrm{aA}$ & $0.38(0.09) \mathrm{bA}$ \\
\hline \multirow{3}{*}{$p$-values } & Intercropping & 0.593 & 0.050 & 0.163 & 0.067 & 0.002 & $<0.0001$ \\
\hline & Year & 0.0001 & $<0.0001$ & $<0.0001$ & $<0.0001$ & $<0.0001$ & $<0.0001$ \\
\hline & Int. $\times$ Year & 0.736 & 0.971 & 0.983 & 0.499 & 0.07 & 0.969 \\
\hline
\end{tabular}

Values are treatment means (S.E); different lowercase letters within columns in each year indicate statistical significance at $p \leq 0.05$ level (Tukey's post hoc test) among treatments. Different uppercase letters within columns indicate statistically significant differences between years.

\subsection{Effect of Relay Intercropping on Weed Biomass at Crop Harvest}

The interaction between intercrop density and year affected the weed dry biomass density significantly $(p=0.004)$ (Figure 2$)$. Remarkably, relay intercropping of durum wheat with lentil significantly $(p<0.0001)$ reduced weed density compared to mechanically weeded and un-weeded sole lentil and sole durum wheat. Un-weeded sole cropped lentil was more infested by weeds in $2020\left(767 \pm 151 \mathrm{~g} \mathrm{~m}^{-2}\right)$ compared to $2019\left(584 \pm 52 \mathrm{~g} \mathrm{~m}^{-2}\right)$ and $2021\left(458 \pm 53 \mathrm{~g} \mathrm{~m}^{-2}\right)$. Though mechanical weeding of lentil significantly reduced weed biomass compared to the un-weeded system, higher weed infestation levels were observed on mechanically weeded sole lentil in $2021\left(296 \pm 45 \mathrm{~g} \mathrm{~m}^{-2}\right)$ compared to 2020 $\left(51 \pm 14 \mathrm{~g} \mathrm{~m}^{-2}\right)$ (Figure 2).

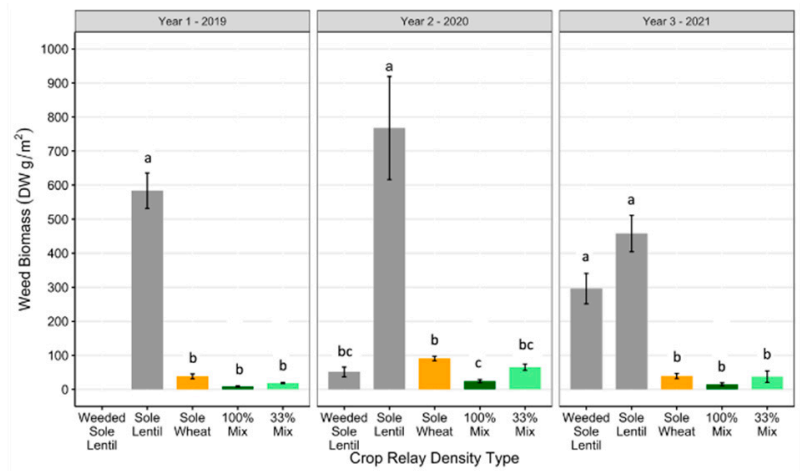

Figure 2. Aboveground weed biomass dry weight $\left(\mathrm{g} \mathrm{m}^{-2}\right)$ in 2019, 2020 and 2021 seasons at crop harvest: $100 \%$ mix, high-density wheat + lentil; 33\% mix, low-density wheat + lentil; different lowercase letters within each year indicate statistical significance at $p \leq 0.05$ level (Tukey's post hoc test) among all treatments. Error bars represent standard error of the mean (S.E).

\subsection{PCA-Variation among Productivity Components in Sole and Intercropped Systems}

PCA biplot graphs (Figure 3) showed variability of data across the three years, which clustered according to the cropping system used. In the first PCA, two principal components (PCs) accounted for $84 \%$ (PC1-63.4\%, PC2-20.6\%) of the total variance in durum wheat production (Figure $3 \mathrm{~A}$ ). Production related durum wheat traits (grain yield, spike number, spike biomass, and aboveground biomass) correlated with PC1 while $\mathrm{HI}$ and weed biomass correlated with PC2. In the second PCA, PC1 (59\%) and PC2 (30.4\%) accounted for 89.4\% of the total variance in lentil production (Figure 3B). Evidently, there was a clear separation 
of production variables between sole cropped and intercropped lentils. Weed biomass negatively correlated with lentil HI.
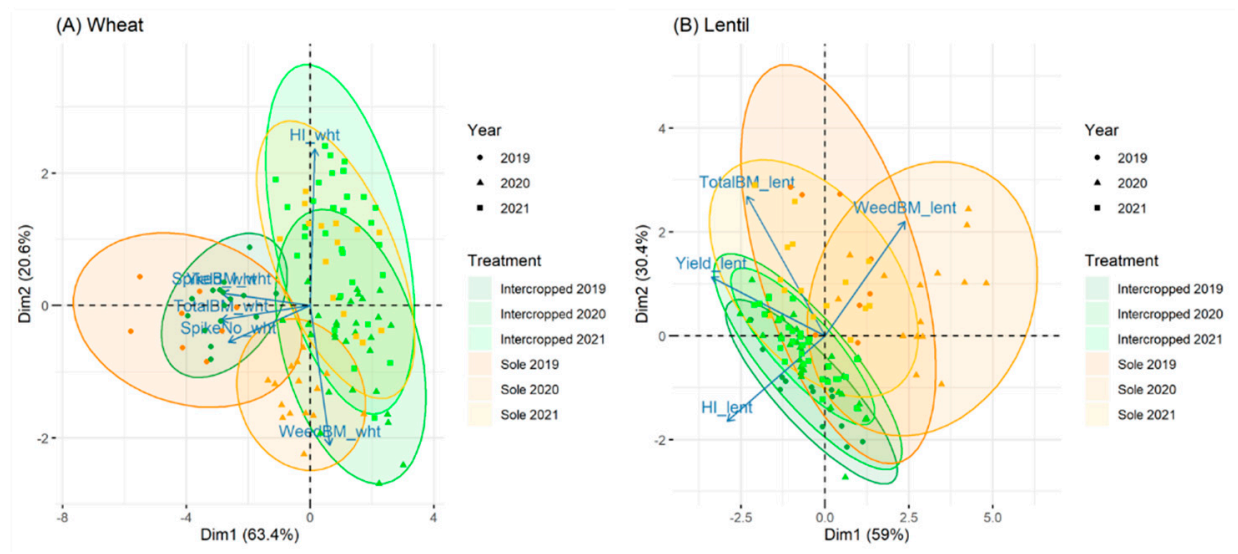

Figure 3. Principal component analysis (PCA) representation of production related variables of (A) wheat and (B) lentils in sole and intercropped systems. HI, harvest index; spikeBM, spike biomass; spikeNo, spike number; weedBM, weed biomass; TotalBM, total aboveground biomass; lent, lentil; wht, durum wheat.

\section{Discussion}

\subsection{Intercrop Productivity under Contrasting Climatic Conditions}

In this study, the contrasting climatic conditions across the three growing seasons turned out to be an important factor that affected, to a greater extent, durum wheat growth and productivity in 2020 and 2021 as compared to 2019 (Figure 3). The excess rainfall during the durum wheat sowing period (November-December 2019; Figure 1) significantly delayed the sowing of durum wheat in the 2020 season. This delay did not affect seedling emergence but significantly reduced the wheat TI compared to 2019 and 2021. Winter durum wheat requires longer, cooler months to optimally accumulate dry matter at their early stages, i.e., before flowering. Therefore, late sowing reduces the total dry matter production, thus decreasing the amount of wheat dry matter converted by wheat into grains [25]. In the 2021 season, durum wheat seedling emergence was on average reduced by $53 \%$ compared to the target density. This could be attributed to the unprecedented heavy rainy conditions between December 2020 and January 2021 (Figure 1). Lentil, grown later as spring crops, was not affected, and had seedling emergence that consistently matched the planned density across the three years.

In line with our first hypothesis, relay intercropping significantly reduced lentil biomass but enhanced the lentil HI in 2019 and 2021 and grain yield in 2020 compared to the un-weeded sole lentil. This was likely associated with the competition effect of wheat that might have reduced lentil biomass growth. The competition indices A and CR clearly showed the dominance of wheat over lentil in 2019 and 2021. This dominance may have enhanced weed suppression and the physiological conversion of the lentil dry matter and assimilates to grain development as supported by the high HI of the intercropped lentil. In addition, it was evident that the total intercrop biomass and grain yield were always higher than that of lentil and durum wheat sole crops, despite the seasonal effects. These results confirmed the findings of Latati et al. [18], who reported a reduction in chickpea biomass when intercropped with durum wheat, but an increase in the overall productivity as indicated by high LER values in the intercropping system. Contrary to our hypothesis, we observed a marginal reduction effect of intercropping on durum wheat spike productivity and grain yield compared to that of sole crop. Advantageously, the marginal reduction in wheat yield in the intercropping system could be compensated by the high-valued lentils. This portrays the plasticity of the intercropping system in stabilizing yields and maximizing the potential profitability despite seasonal variations. 
Based on the LER index, the results from both intercropping systems showed a consistent grain yield advantage (LER $>1$ ) of durum wheat-lentil mixtures compared to sole crops despite the variable weather conditions across the growing seasons. This suggests that the interspecific facilitation and complementarity in the use of natural resources was greater than the competition, thus resulting in greater land-use efficiency in the tested intercropping systems. The highest yield advantage recorded in 2020 could be attributed to the high yielding effect of the intercropped lentil as compared to the sole lentil crops whose growth, productivity, and harvest efficiency were heavily disadvantaged by weeds. In addition, in the same season, a delay in durum wheat sowing shortened its development cycle and lowered wheat dominance and aggressiveness over lentil. These unexpected conditions favored the productivity of the high-valued lentil, thus could have safeguarded farmers' profitability by compensating the possible yield losses that could have occurred in the case of durum wheat monocropping. Our LER results support the findings of Loïc et al. [10] and Latati et al. [18], who reported high yield advantages with LER ranging between 1.02 to 1.80 in spring wheat-lentil and wheat-chickpea mixtures, respectively, cultivated in seasons with contrasting climatic conditions. Both studies attributed overyielding in the intercropping systems to better utilization efficiency of resources via interspecific complementarity and facilitation processes. In our study, lentil was relay intercropped into the already developed durum wheat (at the tillering stage), thus minimizing early competition with the main crop while maximizing resource facilitation and sharing at the later stages of both intercrops.

\subsection{Intercropping Densities and Competition}

In line with our second hypothesis, reducing wheat density in the intercropping enhanced lentil biomass accumulation compared to the lentil intercropped with durum wheat at high density in 2019. In 2020 and 2021, when the wheat dominance was relatively low due to poor development, the intercropped lentil biomass did not significantly differ in both intercropping systems. A similar effect was noted on lentil HI of the intercrops. These observations suggest that the competitive ability of durum wheat in the two intercropping systems was not high enough to significantly suppress the lentil growth significantly, particularly in 2020 and 2021, thanks to the seasonal variation that altered crop species competitiveness and their interspecific interactions. In addition, the durum wheat sown at low density produced heavier spikes which compensated for the reduced density, hence recording spike biomass comparable to that of wheat sown at high density. Pure wheat stands experience less competition, i.e., only intraspecific competition, whereas mixed stands of wheat and lentil are likely to experience both interspecific and intraspecific competitions [45] for the bio-resources that are often limiting in the context of low input systems.

The CR indices of durum wheat were significantly higher in the less-dense system compared to the highly-dense system, and this observation was strongly evident in 2019 and 2021. Reducing durum wheat density to 33\% of the standard sowing quantity, and timely sowing during the cooler winter months, allowed wheat enough time to develop, i.e., shooting and tillering. These advantages were not observed in 2020, where delayed sowing significantly lowered durum wheat $(\mathrm{A}<0)$ dominance over lentil. These variations suggest that under different climatic conditions, wheat competitiveness and dominance over lentil could be altered depending on the objective of the farmer. Late sowing of durum wheat under high density could reduce competition pressure on lentil, therefore favoring lentil cultivation which fetches higher prices (3-4 times higher price than durum wheat [10]).

\subsection{Intercrops' Functional Trait Complementarity: P Uptake and Weed Control}

In this study, we observed an increasing trend in P concentration in the shoots of the intercropped durum wheat at flowering stage, which was in line with our third hypothesis. However, a decreasing trend in P concentration was observed in intercropped lentil. This suggests that lentil probably facilitated $\mathrm{P}$ availability for use by the companion durum 
wheat. Legumes in symbiotic association with rhizobia, can biologically fix atmospheric $\mathrm{N}_{2}$ into the rhizosphere [46,47], and can share up to $15 \%$ of the $\mathrm{N}$ with the cereals [48], while modulating $\mathrm{P}$ availability and sharing through enhanced microbial and extra-radical biochemical networks [49]. Perhaps, the extensively intertwined root and hyphal mycorrhizal network complexes in intercrops provide an expanded root surface area to which nutrients can be exchanged [50]. The findings of our study are further supported by the findings of Morris and Garrity [51], who demonstrated that $\mathrm{P}$ and $\mathrm{K}$ assimilation in intercropping was higher $(43 \% \mathrm{P}, 35 \% \mathrm{~K})$ in intercrops than in pure crop stands. Facilitation occurs when one of the intercrops improves the growth, nutrient uptake, and productivity of the companion species [52]. However, this is not always the case, especially in rain-fed low-input agricultural systems. Abiotic factors such as soil type, nutrient availability, and local climatic conditions influence the outcome of interspecific plant interactions [23]. The lentil nutrient uptake efficiency in our two intercropping systems might have been rendered less efficient by the durum wheat despite reducing its density to $33 \%$. This confirms the observations from Loïc et al. [10], who similarly reported spring wheat dominance over lentil despite reducing wheat density to $17 \%$ in wheat-lentil intercropping. Therefore, finding the optimum density configuration for the dominant cereal without compromising its yield capacity could maximize nutrient uptake of the intercrops.

As hypothesized (hypothesis iv), the combination of durum wheat and lentil in both intercropping systems significantly reduced weed biomass compared to the lentil sole crop. The canopy of the two mixtures enhanced ground cover, limiting the space available for optimal weed growth [21]. Moreover, the allelopathic root exudates produced by durum wheat may have contributed to suppressing weed germination and slowing weed development [15], thus benefiting the intercropped lentil. From our results, it was evident that there was a higher weed pressure in the field used in 2020 than in any other season. In fact, mechanical harvesting of sole cropped lentil was not possible and could have resulted in $100 \%$ yield loss in that season was it not for our hand harvesting approach. Advantageously, intercropping resulted in a $300 \%$ potential yield increase compared to the un-weeded sole lentil. This weed suppression property is supported by the results of the PCA (Figure 3B) and the findings reported by Banik et al. [53] on wheat-chickpea, and Carr et al. [22] on wheat-lentil mixtures. Owing to their differences in canopy height and growth habit of the component species, intercrops develop some sort of synergism in light interception and nutrient uptake that interferes with the availability of resources exploitable by weeds. Mechanical weed control could be a solution for low-input farmers, but it may increase production costs, hence reducing farmers' returns. In this view, the result of this study suggests that intercropping can be as effective as hoeing in controlling weeds within our low-input context.

\section{Conclusions}

This study showed that despite contrasting climatic conditions, intercropping of winter durum wheat with spring lentil can increase the overall aboveground biomass and grain production per unit area compared to sole crops. No adverse competition effects between the intercrops were observed, hence a yield advantage in both intercropping systems over the sole crops. At the crop species level, relay intercropping slightly reduced the lentil shoot $P$ concentration but favored $P$ accumulation in durum wheat shoots. Reducing wheat density did not considerably lower durum wheat grain production compared to the highly dense intercropping system. The complementary functional traits of durum wheat-lentil intercrops effectively controlled weeds comparable to mechanical hoeing. Finally, it was evident that climate variability can increase the risk of yield losses; nevertheless, relay intercropping of durum wheat with lentil proved to stabilize overall crop productivity. However, further economic analysis capturing the additional costs incurred in intercropping and mechanical weeding would highlight the actual profitability of these systems. 
Supplementary Materials: The following are available online at https:/ /www.mdpi.com/article/10 .3390/agronomy12010210/s1, Table S1: Crop emergence and durum wheat spike number and spike biomass at harvest as affected by intercropping density and year. Values are treatment means (S.E); different lowercase letters within columns in each year indicate statistical significance at $p \leq 0.05$ level (Tukey's post hoc test) among treatments. Different uppercase letters within columns indicate statistically significant differences between years.

Author Contributions: Conceptualization, G.K., F.L., S.C., L.A. and P.B.; methodology, G.K., F.L., S.C. and P.B.; data analysis, G.K., F.L. and S.C.; original draft preparation, G.K.; review and editing, G.K., F.L., S.C., L.A. and P.B.; supervision, F.L., L.A. and P.B.; project administration, P.B.; funding acquisition, P.B. All authors have read and agreed to the published version of the manuscript.

Funding: This work was supported by the European Union's Horizon 2020-LEGVALUE program, and Scuola Superiore Sant'Anna. G.K. has a study grant from the Ph.D. program in Agrobiodiversity at Scuola Superiore Sant'Anna, Pisa, Italy.

Institutional Review Board Statement: Not applicable.

Informed Consent Statement: Not applicable.

Data Availability Statement: The data that support the findings of this study are available from the corresponding author upon request.

Acknowledgments: The authors would like to thank Mariateresa Lazzaro and Fernando Pellegrini for their input in conceptualizing this study. In addition, we would like to thank Giacomo Nardi and all the technicians of the Centre for Agri-Environmental Research "Enrico Avanzi" of the University of Pisa for their technical support and in managing the field trials.

Conflicts of Interest: The authors declare no conflict of interest.

\section{References}

1. Pérez-Escamilla, R. Food Security and the 2015-2030 Sustainable Development Goals: From Human to Planetary Health. Curr. Dev. Nutr. 2017, 1, e000513. [CrossRef]

2. Maitra, S.; Hossain, A.; Brestic, M.; Skalicky, M.; Ondrisik, P.; Gitari, H.; Brahmachari, K.; Shankar, T.; Bhadra, P.; Palai, J.B.; et al. Intercropping-A Low Input Agricultural Strategy for Food and Environmental Security. Agronomy 2021, 11, 343. [CrossRef]

3. Chen, P.; Du, Q.; Liu, X.; Zhou, L.; Hussain, S.; Lei, L.; Song, C.; Wang, X.; Liu, W.; Yang, F.; et al. Effects of reduced nitrogen inputs on crop yield and nitrogen use efficiency in a long-term maize-soybean relay strip intercropping system. PLoS ONE 2017, 12, e0184503. [CrossRef] [PubMed]

4. Jensen, E.S.; Carlsson, G.; Hauggaard-Nielsen, H. Intercropping of grain legumes and cereals improves the use of soil N resources and reduces the requirement for synthetic fertilizer N: A global-scale analysis. Agron. Sustain. Dev. 2020, 40, 5. [CrossRef]

5. Tanveer, M.; Anjum, S.A.; Hussain, S.; Cerdà, A.; Ashraf, U. Relay cropping as a sustainable approach: Problems and opportunities for sustainable crop production. Environ. Sci. Pollut. Res. 2017, 24, 6973-6988. [CrossRef]

6. Amossé, C.; Jeuffroy, M.H.; David, C. Relay intercropping of legume cover crops in organic winter wheat: Effects on performance and resource availability. Field Crop. Res. 2013, 145, 78-87. [CrossRef]

7. Kammoun, B.; Journet, E.-P.; Justes, E.; Bedoussac, L. Cultivar Grain Yield in Durum Wheat-Grain Legume Intercrops Could Be Estimated From Sole Crop Yields and Interspecific Interaction Index. Front. Plant Sci. 2021, 12, 128. [CrossRef]

8. Gecaitè, V.; Arlauskienè, A.; Cesevičienè, J. Competition Effects and Productivity in Oat-Forage Legume Relay Intercropping Systems under Organic Farming Conditions. Agriculture 2021, 11, 99. [CrossRef]

9. Yang, C.; Fraga, H.; van Ieperen, W.; Santos, J.A. Assessing the impacts of recent-past climatic constraints on potential wheat yield and adaptation options under Mediterranean climate in southern Portugal. Agric. Syst. 2020, 182, 102844. [CrossRef]

10. Loïc, V.; Laurent, B.; Etienne-Pascal, J.; Eric, J. Yield gap analysis extended to marketable grain reveals the profitability of organic lentil-spring wheat intercrops. Agron. Sustain. Dev. 2018, 38, 39. [CrossRef]

11. Shao, Z.-Q.; Zheng, C.-C.; Postma, J.A.; Lu, W.L.; Gao, Q.; Gao, Y.Z.; Zhang, J.J. Nitrogen acquisition, fixation and transfer in maize/alfalfa intercrops are increased through root contact and morphological responses to interspecies competition. J. Integr. Agric. 2021, 20, 2240-2254. [CrossRef]

12. Kraska, P.; Andruszczak, S.; Kwiecinska-Poppe, E.; Staniak, M.; Rózyło, K.; Rusecki, H. Supporting crop and different row spacing as factors influencing weed infestation in lentil crop and seed yield under organic farming conditions. Agronomy 2020, 10, 9. [CrossRef]

13. Li, L.; Tilman, D.; Lambers, H.; Zhang, F.-S. Plant diversity and overyielding: Insights from belowground facilitation of intercropping in agriculture. New Phytol. 2014, 203, 63-69. [CrossRef] 
14. Bargaz, A.; Noyce, G.L.; Fulthorpe, R.; Carlsson, G.; Furze, J.R.; Jensen, E.S.; Dhiba, D.; Isaac, M.E. Species interactions enhance root allocation, microbial diversity and P acquisition in intercropped wheat and soybean under P deficiency. Appl. Soil Ecol. 2017, 120, 179-188. [CrossRef]

15. Leoni, F.; Hazrati, H.; Fomsgaard, I.S.; Moonen, A.C.; Kudsk, P. Determination of the Effect of Co-cultivation on the Production and Root Exudation of Flavonoids in Four Legume Species Using LC-MS/MS Analysis. J. Agric. Food Chem. 2021, 69, 9208-9219. [CrossRef]

16. Tosti, G.; Guiducci, M. Durum wheat-faba bean temporary intercropping: Effects on nitrogen supply and wheat quality. Eur. J. Agron. 2010, 33, 157-165. [CrossRef]

17. Mariotti, M.; Masoni, A.; Ercoli, L.; Arduini, I. Optimizing forage yield of durum wheat/field bean intercropping through N fertilization and row ratio. Grass Forage Sci. 2012, 67, 243-254. [CrossRef]

18. Latati, M.; Dokukin, P.; Aouiche, A.; Rebouh, N.Y.; Takouachet, R.; Hafnaoui, E.; Hamdani, F.Z.; Bacha, F.; Ounane, S.M. Species interactions improve above-ground biomass and land use efficiency in intercropped wheat and chickpea under low soil inputs. Agronomy 2019, 9, 765. [CrossRef]

19. Bedoussac, L.; Journet, E.P.; Hauggaard-Nielsen, H.; Naudin, C.; Corre-Hellou, G.; Jensen, E.S.; Prieur, L.; Justes, E. Ecological principles underlying the increase of productivity achieved by cereal-grain legume intercrops in organic farming. A review. Agron. Sustain. Dev. 2015, 35, 911-935. [CrossRef]

20. Pellegrini, F.; Carlesi, S.; Nardi, G.; Arberi, P.B. Wheat-clover temporary intercropping under Mediterranean conditions affects wheat biomass, plant nitrogen dynamics and grain quality. Eur. J. Agron. 2021, 130, 126347. [CrossRef]

21. Wang, L.; Gruber, S.; Claupein, W. Optimizing lentil-based mixed cropping with different companion crops and plant densities in terms of crop yield and weed control. Org. Agric. 2012, 2, 79-87. [CrossRef]

22. Carr, P.M.; Gardner, J.C.; Schatz, B.G.; Zwinger, S.W.; Guldan, S.J. Grain yield and weed biomass of a wheat-lentil intercrop. Agron. J. 1995, 87, 574-579. [CrossRef]

23. Faucon, M.P.; Houben, D.; Lambers, H. Plant Functional Traits: Soil and Ecosystem Services. Trends Plant Sci. 2017, 22, 385-394. [CrossRef] [PubMed]

24. Nargis, A.; Alim, M.A.; Islam, M.M.; Zabun, N.; Maksuder, R.; Hossain, A.S.M.I. Iqbal Hossain Evaluation of Mixed and Intercropping of Lentil and Wheat. J. Agron. 2004, 3, 48-51. [CrossRef]

25. Arduini, I.; Ercoli, L.; Mariotti, M.; Masoni, A. Sowing date affect spikelet number and grain yield of durum wheat. Cereal Res. Commun. 2009, 37, 469-472. [CrossRef]

26. Soil Survey Stuff (Ed.) Soil Taxonomy: A Basic System of Soil Classification for Making and Interpreting Soil Surveys, 2nd ed.; United States Department of Agriculture (USDA): Washinghton, DC, USA, 1999; Volume 2.

27. IUSS Working Group WRB. World Reference Base for Soil Resources 2014, Update 2015 International Soil Classification System for Naming Soils and Creating Legends for Soil Maps; World Soil Resources Reports No. 106; Food and Agriculture Organization: Rome, Italy, 2015.

28. Bremner, J.M. Determination of nitrogen in soil by the Kjeldahl method. J. Agric. Sci. 1960, 55, 11-33. [CrossRef]

29. Nelson, D.W.; Sommers, L.E. Total Carbon, Organic Carbon, and Organic Matter. In Methods of Soil Analysis, Part 3: Chemical Methods; Sparks, D.L., Page, A.L., Helmke, P.A., Loeppert, R.H., Eds.; John Wiley \& Sons, Ltd.: Hoboken, NJ, USA, 1996; Volume 3 , pp. 961-1010, ISBN 9780891188667.

30. Olsen, S. Estimation of Available Phosphorus in Soils by Extraction with Sodium Bicarbonate; United States Department of Agriculture: Washington, DC, USA, 1954; Volume 939.

31. Agroservice, S. Lentil cv. Elsa-Agroservice SPA. Available online: https://www.agroservicespa.it/en/prodotti/view/elsa_ lenticchia_eng.html (accessed on 16 December 2021).

32. Agroservice, S. Durum Wheat cv. Minosse-Agroservice SPA. Available online: https://www.agroservicespa.it/en/prodotti/ view/minosse_frumento_duro_eng.html (accessed on 16 December 2021).

33. Meier, U.; Bleiholder, H.; Buhr, L.; Feller, C.; Hack, H.; Heß, M.; Lancashire, P.D.; Schnock, U.; Stauß, R.; Van Den Boom, T.; et al. The BBCH System to Coding the Phenological Growth Stages of Plants-History and Publications, 2nd ed.; Meier, U., Ed.; Federal Biological Research Centre for Agriculture and Forestry: Berlin, German, 2009; Volume 61.

34. Lazzaro, M.; Bàrberi, P.; Dell'Acqua, M.; Pè, M.E.; Limonta, M.; Barabaschi, D.; Cattivelli, L.; Laino, P.; Vaccino, P. Unraveling diversity in wheat competitive ability traits can improve integrated weed management. Agron. Sustain. Dev. 2019, 39, 6. [CrossRef]

35. Willey, R.; Rao, M. A competitive ratio for quantifying competition between intercrops. Exp. Agric. 1980, 16, 117-125. [CrossRef]

36. Dariush, M.; Ahad, M.; Meysam, O. Assessing the Land Equivalent Ratio (Ler) of Two Corn [Zea mays L.] Varieties Intercropping At Various Nitrogen Levels in Karaj, Iran. J. Cent. Eur. Agric. 2006, 7, 359-364. [CrossRef]

37. McGilchrist, C. Analysis of competition experiments. Biometrics 1965, 1, 975-985. [CrossRef]

38. Dhima, K.V.; Lithourgidis, A.S.; Vasilakoglou, I.B.; Dordas, C.A. Competition indices of common vetch and cereal intercrops in two seeding ratio. Field Crop. Res. 2007, 100, 249-256. [CrossRef]

39. R Core Team R: A Language and Environment for Statistical Computing. Available online: https://www.r-project.org/ (accessed on 25 July 2021).

40. Bates, D.; Mächler, M.; Bolker, B.M.; Walker, S.C. Fitting linear mixed-effects models using lme4. J. Stat. Softw. 2015, 67, 1-48. [CrossRef] 
41. Lenth, R. Emmeans: Estimated Marginal Means. Available online: https://github.com/rvlenth/emmeans (accessed on 25 July 2021).

42. Akaike, H. A new look at the statistical model identification. IEEE Trans. Automat. Contr. 1974, 19, 716-723. [CrossRef]

43. Hartig, F.; Lohse, L. Residual Diagnostics for Hierarchical (Multi-Level/Mixed) Regression Models. Available online: https: / / cran.r-project.org / package=DHARMa (accessed on 25 July 2021).

44. Kaiser, H.F. The varimax criterion for analytic rotation in factor analysis. Psychometrika 1958, 23, 187-200. [CrossRef]

45. Zhang, G.; Yang, Z.; Dong, S. Interspecific competitiveness affects the total biomass yield in an alfalfa and corn intercropping system. Field Crop. Res. 2011, 124, 66-73. [CrossRef]

46. Koskey, G.; Mburu, S.W.; Njeru, E.M.; Kimiti, J.M.; Ombori, O.; Maingi, J.M. Potential of native rhizobia in enhancing nitrogen fixation and yields of climbing beans (Phaseolus vulgaris L.) in contrasting environments of eastern Kenya. Front. Plant Sci. 2017, 8 , 443. [CrossRef] [PubMed]

47. Koskey, G.; Mburu, S.W.; Awino, R.; Njeru, E.M.; Maingi, J.M. Potential Use of Beneficial Microorganisms for Soil Amelioration, Phytopathogen Biocontrol, and Sustainable Crop Production in Smallholder Agroecosystems. Front. Sustain. Food Syst. 2021, 5, 130. [CrossRef]

48. Li, Y.; Ran, W.; Zhang, R.; Sun, S.; Xu, G. Facilitated legume nodulation, phosphate uptake and nitrogen transfer by arbuscular inoculation in an upland rice and mung bean intercropping system. Plant Soil 2009, 315, 285-296. [CrossRef]

49. Xue, Y.; Xia, H.; Christie, P.; Zhang, Z.; Li, L.; Tang, C. Crop acquisition of phosphorus, iron and zinc from soil in cereal/legume intercropping systems: A critical review. Ann. Bot. 2016, 117, 363-377. [CrossRef] [PubMed]

50. Njeru, E. Crop Diversification: A Potential Strategy To Mitigate Food Insecurity by Smallholders in sub-Saharan Africa. J. Agric. Food Syst. Community Dev. 2013, 3, 63-69. [CrossRef]

51. Morris, R.A.; Garrity, D.P. Resource capture and utilization in intercropping; non-nitrogen nutrients. Field Crop. Res. 1993, 34 319-334. [CrossRef]

52. Duchene, O.; Vian, J.F.; Celette, F. Intercropping with legume for agroecological cropping systems: Complementarity and facilitation processes and the importance of soil microorganisms. A review. Agric. Ecosyst. Environ. 2017, 240, 148-161. [CrossRef]

53. Banik, P.; Midya, A.; Sarkar, B.K.; Ghose, S.S. Wheat and chickpea intercropping systems in an additive series experiment: Advantages and weed smothering. Eur. J. Agron. 2006, 24, 325-332. [CrossRef] 